\title{
The Marketisation of Charities in England and Wales
}

\begin{abstract}
Much has been written about the reasons for and impact of marketisation on charities, their clients, and wider civil society. A central component of the marketisation thesis is that charities are substituting grants and donations with commercial revenue. However there is no consensus in the existing literature as to whether the two sources of revenue are substitutes or complementary. This paper shows that between 2003 and 2007 there was a significant increase in the proportion of overall revenue attracted from commercial sources by charities in England and Wales. Using our preferred Generalised Method of Moments (GMM) estimation model we show that the annual persistence of commercial revenue over time was $44 \%$. In particular, $a+10 \%$ change in grants and donations was associated with a $-3.1 \%$ change in commercial revenue.
\end{abstract}

Keywords Charities, crowding out, marketisation, models with Panel Data, nonprofit, revenue mix, substitution effect

\section{Introduction}

Charitable activity has traditionally caused much anguish for neoclassical economists as philanthropy, volunteering and co-operative behaviour fall outside of the scope of rational choice behaviour. Indeed, the very existence of charities poses fundamental questions to neoclassical economic theory (Halfpenny and Reid 2002) which sees the world as bound by market exchange, rational choice and self-interested utility maximisation (Adaman and Madra 2002). The economic explanation is to imply that charities exist because of imperfect or underdeveloped markets for public goods (Weisbrod 1975). However they are productively inefficient when compared to the private firm due to their "non-distribution constraint.' Effectively managers of charities have no incentive to minimise costs (Hansmann 1987), and so are 'crowded-out' in fields where markets are well developed, but are overrepresented in fields such as health and social services where many consumers are unable to pay a market rate for the goods they consume (Hansmann 1987). If conventional economic theory treats charities as an inefficient anomaly then the 'solution' is to propose that they behave as private firms in efficient markets. Achieving this 'solution' necessitates improving the operation of markets for public goods, and introducing market discipline to charities (Tsakalotos 2005). 
It would appear that this neo-classical 'solution' is occurring in some countries. Since the 1980s Governments of both major parties in the United Kingdom have attempted to create more efficient markets for public goods through opening up the market for delivery of public services to providers from private and third sectors on a 'best value' basis (Newman 2007). This process accelerated under the recent New Labour government as charities were given an enhanced role in economic policy (Haugh and Kitson 2007). Another increasingly important aspect to this marketisation of the nonprofit sector involves the direct sale of goods and services by charities to consumers (Eikenberry and Kluver 2004), and a more recent innovation, the creation of subsidiary social enterprises with the primary aim of providing employment to clients (Teasdale 2010). Business and management scholars have turned their attention to nonprofits en masse to help them adapt to their new commercial environment (Dey and Steyaert 2010). A range of 'how to' texts set out simple steps for nonprofits to follow in order to avoid dependence on grants and donations by increasing their share of commercial revenue, and to become more efficient through the imposition of market discipline (see for example Dees et al. 2001).

A counter discourse warns of the dangers of this 'economic fallacy'. In seeing things through a neoclassical lens that excludes the possibility of behaviour not bound by market exchange and rational choice (Adaman and Madra 2002) we risk creating a world which loses sight of those values such as reciprocity, philanthropy and democracy (Tsakalotos 2005). The study of nonprofits through this lens has valorised a particular income source - commercial revenue (Eikenberry, 2009), and a particular form - the social enterprise (Dey and Steyaert 2010). As a consequence it is argued that nonprofits are behaving more like businesses in replacing traditional sources of revenue with commercial revenue because they are expected, or even compelled to do so, rather than any rational assessment of the financial and social implications (Dart 2004; Eikenberry and Kluver 2004).

The purpose of this paper is not to further develop the literature explaining marketisation and its consequences. For while much has been written about the reasons for, and implications of, charities succumbing to market forces, rather less attention has been paid to developing the evidence base to support (or deny) the underlying assumptions upon which the marketisation thesis rests. In this paper we address this deficit by answering the critical question: are charities substituting commercial revenue for grants and donations, or are the two income sources in fact complementary? To do this we constructed a large panel data set derived from registered general charities' annual returns to the Charity Commission for England and Wales for the period 2002-2008.' These returns were each analysed to determine 
the proportion of revenue attracted through commercial sources (fees for goods and services; and surplus generated from subsidiary trading operations), and voluntary income (grant and private donations). ii All charities were classified according to the International Classification of Nonprofit Organisations (ICNPO) system. Using our preferred Generalised Method of Moments (GMM) estimation model we found that commercial revenue was an inelastic substitute for grants and donations. Hence we conclude that marketisation of charities in England and Wales is occurring to a limited extent.

\section{The Marketisation Thesis}

The term marketisation is used to refer to nonprofits becoming "more market driven, client driven, self-sufficient, commercial or business like" (Dart 2004, p. 414) that is, adopting the languages, practices and funding mechanisms of the private sector. It is possible to distinguish between two broad but overlapping aspects of marketisation. The first involves nonprofits seeking to mimic the organisational structures, practices and languages of the private sector. To some extent this trend also involves the re-labelling of charitable activity as social entrepreneurship, and there is a wide literature developing that follows this tradition, particularly in business and management schools (see Dees 2007). The second aspect of marketisation which particularly concerns us in this paper focuses more narrowly on the ways in which nonprofits are funded. That is a supposed transfer from grants and donations to commercial revenue.

Commercial revenue is itself a broad category (See Table 1) which is generally used to include program service fees; the sale of products not directly associated with the charitable activity; contracts to deliver services on behalf of a third party; profits from forprofit subsidiaries; and fees for endorsing products (Dart 2004; Eikenberry and Kluver 2004; Kerlin and Pollak 2011).

\section{Table 1 Here}

\section{Aggregate trends in marketisation}

While charities attracting commercial revenue is not a new phenomenon (Teasdale2010), it is widely accepted that their reliance on commercial sources has increased significantly since the 1970s, and now makes up the largest source of revenue in both the US (Kerlin and Pollak 2011) and England and Wales (NCVO 2010). This trend is widely attributed in the United States to a decline in government grants and private contributions in the 1970s and 1980s leading nonprofits to pursue new revenue sources (Dees 1998; Eikenberry and Kluver 2004; Froelich 1999; Salamon 1993, 1997). When counter posed with an aggregate increase in 
commercial revenue (Salamon 1997), an assumption is made that commercial revenue was (and more importantly, remained) a substitute for grants and donations for the sector as a whole (Eikenberry 2009).

However, a systematic analysis of trends in nonprofit commercial activity in the US between 1982 and 2002 shows that while commercial revenue rose by $219 \%$ over the period, private donations and government grants also rose (by 197\% and 169\% respectively) (Kerlin and Pollak 2011). Other studies are inconclusive, and have drawn on small samples (LeRoux 2005), focused on limited subfields within the sector (Guo 2006; Kingma 1995), or relied on changes between two time points rather than attempting to show trends (Foster and Bradach 2005; Teasdale et al. 2013). Thus the only reliable evidence we have is that in the US there has been a gradual increase in the proportion of revenue attracted from commercial sources by nonprofits. This has been accompanied by a real increase in government grants and private giving to nonprofits over the same period (Kerlin and Pollak 2011). But the marketisation thesis implies more than a gradual trend for charities to increase the proportion of their income attracted from commercial revenue. The term marketisation is used explicitly to refer to the substitution of traditional sources of nonprofit funding, that is grants and donations, by commercial revenues (Eikenberry and Kluver 2004).

In England and Wales the changing political and economic environment during the period of Labour government between 1997 and 2009 are likely to have impacted upon charities' revenue streams. Nicholls (2010) shows that in the US foundations, such as the Ashoka and the Skoll Foundation, funded by the private sector, and promoting the market logics of that sector, are the dominant drivers of the commercialisation of nonprofits. He notes that a major difference in England and Wales is the enhanced role played by government in coercing charities to become more business-like. For example, major grant programmes designed to facilitate charities becoming more sustainable through attracting commercial revenues, and the government's creation and funding of umbrella bodies to provide support to nonprofits attracting trading income (Carmel and Harlock 2008; Haugh and Kitson 2007).

A second institutional driver is the changing way in which government funds nonprofits in England and Wales. Under the recent New Labour government there was a pervasive belief that charities and other third sector organisations were best placed to deliver public services due to their responsiveness to the consumer (Haugh and Kitson 2007). As the process of opening up public service delivery to a wider range of private and non-profit providers gathered pace in the new millennium, many charities saw increasing shares of their 
income derived through government contracts (Carmel and Horlock 2008). Together these institutional drivers would suggest that under New Labour, charities in England and Wales have been 'encouraged' to replace grants and donations with commercial income, whether through the delivery of government contracts or the private sale of goods and services. This policy trend has been continued, or even accelerated under a Conservative led coalition government. The Public Services (Social Value) Act was originally intended to enable charities and social enterprises to play an even greater role in the delivery of publicly funded services (Teasdale, Alcock and Smith 2012). Policy measures such as Big Society Capital aim to encourage social investment into charities and social enterprises enabling them to behave more like private firms and scale up in order to repay loan finance.

However there are also opposing (or even complementary) trends which aim to encourage more traditional civil society logics such as self-help, community development, and philanthropy. At the level of the European Union a recent policy focus on social innovation sometimes goes beyond marketization to stress the role of citizen engagement (Davies and Simon 2013) and new approaches to increase charitable giving such as crowd funding (Caulier-Grice et al. 2013). Similarly one aspect of the Big Society emphasised in the Giving White Paper released by the Cabinet Office (2011) involves encouraging greater giving to charities. An implicit assumption of this dual approach to increasing funds available to non-profits through commercial revenue and philanthropy is that for individual charities, commercial revenue and private donations are complementary.

In England and Wales the annual Almanacs produced by NCVO (see NCVO, 2010) do demonstrate a gradual increase in reliance on commercial sources of revenue by charities since 2001 (see Figure 1). As in the US this increase in commercial revenue has been accompanied by a slightly smaller real terms increase in government and private giving to nonprofits. It would appear then that for the aggregate population of charities, commercial revenue and grants and donations are complementary as both sources have risen in tandem.

\section{Figure 1 Here}

\section{What is happening at the organisational level?}

However it is not clear how the different income sources interact at the level of the individual charity. This is in part because, as in the United States (Kerlin and Pollak 2011), the number of charities has also increased over the same time period. Thus demand for grants and donations (and indeed commercial revenue) may have risen faster than supply. Moreover, the period for which data is available has seen a dramatic increase in the aggregate funding available to charities, much of which came from statutory sources at a time when charities 
became a significant player in social and economic policy for the first time (Clifford et al. 2010; Haugh and Kitson 2007).

Nonetheless, it might be that diversification of revenue streams offers net benefits to charities. Froelich (1999) argues that commercial income shows only moderate revenue volatility (see also Carroll and Stater 2009), and is the most flexible and least restrictive source of income available to nonprofits. From this perspective, pursuing commercial revenue is a rational diversification to reduce resource dependence (Froelich 1999; Caroll and Stater 2009), as the two sources of income may be complementary (Yetman et al. 2009). This may be explained by reputational effects whereby individuals, private firms and governments prefer to buy services from organisations whose high levels of voluntary income indicates legitimacy. Thus as grants and donations increase so does commercial revenue.

To the best of our knowledge there are no studies in England and Wales which draw upon large scale data sets to determine whether commercial income is a substitute or complementary to grants and donations at the level of the individual charity. In the United States where data is available to conduct this analysis, most studies have treated grants and donations as the dependent variable (see for example Okten and Weisbrod 2000; Yetman and Yetman 2003). Even here the evidence is mixed. This is in part due to the methods employed, which are largely descriptive, or unable to incorporate a dynamic model which can control for time effects (Tinkelman and Neely 2011). Where studies have investigated the impact of a change in grants and donations upon commercial revenue the evidence is inconclusive. Segal and Wisbrod (1998) draw upon a relatively small sample of 2,679 nonprofits observed between 1985 and 1993 and showed that after controlling for field and time effects there was a substitution effect in some industries but a complementary effect in others. The overall effect (-0.02) on the log of program service revenues (approximating to commercial revenue) of a one percent change in donations for the whole sample was not statistically significant. Segal and Wesibrod used a fixed effects model, probably the most appropriate technique at the time. However we show in our methodology section that econometric advances since their study mean that statisticians would not choose the same model today. Moreover technological advances in the processing power of computers now permit similar analyses to be carried out using larger samples, or even the full population of charities. Therefore it remains unclear in the United States, and to the best of our knowledge has never been shown in England and Wales, whether charities are succumbing to market forces. Confirming (or denying) the marketisation thesis thus requires revisiting the research question: Is commercial revenue a substitute for grants and donations among charities? 


\section{Data}

In order to determine whether commercial revenue is a substitute for grants and donations, in charities, we constructed a large panel data set using data collated by Guidestar UK from registered charities' annual returns to the Charity Commission in England and Wales. This covered the period 2002-2007. We included only general charities in our analysis. Thus our findings exclude public schools, NHS administered charities, independent hospitals, churches, housing associations, and grant making trusts. Our initial panel consisted of 277,537 observations for all 80,589 general charities providing accounts to the Charity Commission between 2002 and 2007 (i.e. each charity provided an average of 3.4 observations).

To enable analysis by field of activity we matched all charities on our panel to the International Classification of Nonprofit Organisations (ICNPO) system originally developed by Salamon and Anheier (1998) to enable cross-national comparison between nonprofits operating in similar fields, using the ICNPO classification variable derived by $\mathrm{NCVO}^{\mathrm{iii}}$ for all general charities in England and Wales.

Our main variables of interest are organisational size (size) (using overall income as an indicator); field of activity (ICNPO); overall income (i); voluntary income (iv); and commercial revenue (is). Commercial revenue provides our main dependent variable. Voluntary income (iv) was derived from the sub-categories of legacies; individual gift aid donations; individual non-tax effective donations; individual other donations; unspecified individual giving; and grants from other organisations (statutory and private). Commercial revenue (is) was derived from the sub-categories of: activities in furtherance of the charity's objects; activities for generating funds; income from trading subsidiaries (gross) and associated expenditure; and unspecified sales and fees from operating activities. In this analysis we did not use investment income and other income. Although our original panel had observations for overall income $(i)$ for each organisation in the population, for many organisations Guidestar UK was unable to separate commercial revenue (is) from voluntary income (iv). These cases were treated as missing, and so many (predominately smaller) charities were excluded from our analysis.

Some commentators have warned of using English charity accounts to differentiate between income streams particularly for smaller charities (Clifford et al. 2010; Morgan 2010). This is because only those charities with an income of $£ 100,000^{\text {iv }}$ or more are required to publish accounts to the standards set out in the Statement of Recommended Practice 
(SORP) produced by the Accounting standards Board (Charity Commission 2005). SORP standards provide detailed instructions for classifying different income sources. Therefore for those larger charities with an income of $£ 100,000$ or more, data pertaining to commercial revenue and voluntary income are expected to be relatively robust.

We considered further restricting our analysis only to charities with an income of $£ 100,000$ or more in each year of the study. However when we ran our model using only these charities we found that results were virtually identical to those obtained using all charities. Many smaller charities also prepare accounts to SORP standards, although they are not required to do so by law. It may be that the smaller charities in our panel are biased towards those that prepare accounts to SORP standards, as Guidestar UK would have found it easier to separate commercial revenue from grants and donations for these charities.

Our econometric analysis was conducted only using those organisations for which we have figures for total, commercial and voluntary income. It is important to note the bias in our sample towards larger organisations which is to be expected given the reasons pertaining to SORP outlined above.

Figure 2 presents graphically the rise in commercial revenue for the different fields of activity for all charities in our panel where we have an observation for is and $i v$, in both 2003 and 2007. First we note that reliance on commercial revenue has increased across (almost) all fields of activity.

\section{Figure 2 Here}

Table 2 begins to draw out the longitudinal element to our data. Here we see that the proportion of commercial revenue has risen in each year of our study ${ }^{\mathrm{v}}$, and that this appears to be partly, although not wholly associated with a decline in the proportion of voluntary income. This confirms existing findings from NCVO (2010) that charities' reliance on earned income has increased relative to other revenue sources since 2001 in England and Wales. The lower means for all income sources in 2006 shown in Table 2 are probably due to us having more observations from smaller organisations in this year.

\section{Table 2 Here}

Table 3 largely confirms findings from the US that larger nonprofits attract a higher proportion of income from commercial sources than smaller nonprofits (Fischer et al. 2007; Guo 2006). A relatively small number of observations for organisations with an income above $£ 100,000,000$ means findings for this group (which over-represent medical research charities, and organisations not elsewhere classified) should be treated with some caution. 


\section{Econometric Strategy}

In table 4 we show the correlations (all in log scale) between commercial revenue $\left(i s_{i, t}\right)$, total income $\left(i_{i, t}\right)$ and voluntary income $\left(i v_{i, t}\right)$. As can been seen, the bivariate relationships between all the variables are all positive, and are all statistically significant. This largely confirms the data presented by NCVO (2010) showing that for the population of charities before controlling for time and field effects, commercial revenue is complementary to grants and donations. It is worth noting the high association between commercial revenue in consecutive years within organisations, with a 0.86 correlation. This lends support to Froelich's (1999) argument that commercial revenue is relatively stable over time.

\section{Table 4 Here}

In table 5 we describe how much income varies between organisations, and how much income occurs within them over time. The 'between' variation shows the variation between the average values in each organisation, the 'within' variation shows the degree of change for individual organisations over time compared to their own mean. For total income, around 77 per cent of the total variation is between organisations, and 23 per cent within organisations. These figures imply that the grouped nature of the organisational data needs to be captured in any statistical approach, as the observations are clearly not independent of each other.

\section{Table 5 Here}

\section{Methodology}

In order to determine whether commercial revenue is a substitute for grants and donations, and to estimate the strength of any substitution effect, we developed a multivariate analysis which captures the dynamic composition of charities' income over the period covered by our dataset.

All monetary variables are expressed at 2008 constant prices. We use the following specification (1) for charities $(i)$ over time $(t)$. Variables are expressed in natural logarithms and denote: commercial revenue $\left(\boldsymbol{i} \boldsymbol{s}_{i, t}\right)$ and voluntary income $\left(\boldsymbol{i} \boldsymbol{v}_{\boldsymbol{i}, t}\right) . \mathrm{S}$ is a set of sector dummy variables to control for possible effects of different areas of activity (ICNPO classification), $\mathrm{T}$ is a set of time dummies (yearly) to capture both the economic business cycle and the commercialisation effect over time. The last two terms are the components of the error term (with $u_{i}$ capturing charity-specific so-called 'fixed effects'). 
Equation 1. Specification of our model

$$
\begin{gathered}
\ln \left(i s_{i, t}\right)=\alpha_{0}+\alpha_{1} \ln \left(i s_{i, t-1}\right)+\alpha_{2} \ln \left(i v_{i, t}\right)+\beta^{\prime} S+\gamma^{\prime} T+u_{i}+\varepsilon_{i, t} \\
i=1, \ldots, N ; t=1, \ldots, T
\end{gathered}
$$

In this equation $i$ and $t$ label charities and years respectively. We have $\mathbf{N}$ charities observed over T years. $i s_{i, t-1}$ is the one-period lag of the charity's $(\log )$ commercial revenue. $i v_{i, 1}$ is the charity's (log) voluntary income (grants and donations) in the current period. Then $S$ represents a set of dummy variables to capture the field of activity specific effect, while $T$ is set of time dummy variables. With regard to error terms the structure of panel allows us to include: $u_{i}$ which captures any charity-specific unobservable characteristics, while $\varepsilon_{i, t}$ is the normal error term (allowing for the charity specific term).

A negative $\alpha_{2}$, would demonstrate that commercial revenue is a substitute for grants and donations, while a positive $\alpha_{2}$, would demonstrate a crowding in or complementary effect.

The reasons for including the lagged dependent variable $i s_{i, t-1}$ as an independent variable are both econometric and interpretative. From a methodological point of view, the persistence of commercial revenue is very high $(\rho=0.86)$ (see Table 4). From an interpretative point of view any explanation of present commercial revenue necessarily involves considering the role of previous commercial revenue (Tinkelman and Neely 2011).

There are several econometric issues that need to be considered in the estimation of equation (1):

i. Voluntary income $\left(i v_{i, t}\right)$, is assumed to be endogenous - part of the model rather than externally determined. Causality may run in both directions (commercial revenue affects grants and donations and vice versa), with the potential for voluntary income to be correlated with the error term.

ii. Time invariant charity characteristics ('fixed effects') may be correlated with the explanatory variables.

iii. The presence of the lagged dependent variable $i s_{i, t-1}$ gives rise to a problem of autocorrelation in standard linear regression and fixed-effects models.

iv. The panel is unbalanced, with some charities having more observations than others. It has also a short time dimension with small $\mathrm{T}$ and large $\mathrm{N}$.

The above dynamic specification cannot be correctly estimated by a standard pooled linear regression (pooled OLS). The error term is likely to be correlated over time for a given 
charity and this correlation violates an important assumption that is necessary for the consistency of OLS.

An intuitive way to address the fixed effect is to draw out the error term by entering dummy variables for each charity: the Least Squares Dummy Variables approach (LSDV). A similar way to address the same problem is dividing the regression in two steps, first applying a mean-deviation transformation on each variable, than running an OLS on the transformed data. This is the within-group, or just 'within' estimator (WG), estimating the same coefficients as LSDV but with a slightly better standard error.

The LSDV and WG estimators are consistent only if there were no lags of the dependent variable (commercial revenue). However, in a dynamic model, the WG and LSDV estimators are biased (Nickell 1981; Roodman 2006). In order to eliminate such problems we use the General Method of Moments (GMM) adopting the approach of Arellano and Bond (1991) and Blundell and Bond (1998). ${ }^{\text {vi }}$

Two different versions of GMM have been developed to estimate equation (1), based on different approaches to instrumental variables. We estimate both GMM-DIF (differenced - transforming the data) and GMM-SYS (system - instrumenting differenced values with levels). These are intended to deal with the endogeneity of some explanatory variables. We use the Sargan test (Sargan 1958) and the Hansen test (Hansen 1982) for over-identification of instruments and the first and second order serial correlations to choose our best specification of the model and the best set of instruments. The Sargan test (Sargan 1958) and Hansen test (Hansen 1982) require the non-rejection of the null hypothesis that the instruments are valid. The first and second order serial correlations test (Arellano and Bond 1991) require the rejection of the null hypothesis of first order serial correlation and at the same time not rejecting the null hypothesis of second order correlation. We compute a robust Windmeijer (finite sample) corrected covariance matrix (see Windmeijer 2005).

\section{Results and Interpretation}

In estimating equation (1) we anticipate a positive $\alpha_{1}$ capturing the persistence effect of previous commercial revenue. A negative $\alpha_{2}$, would demonstrate that voluntary and commercial revenue are substitutes, while a positive $\alpha_{2}$, would demonstrate that commercial and voluntary income are complementary. If $\alpha_{2}$ were to vary considerably by field of activity this would show that any substitution effect between voluntary and commercial revenue varies significantly across fields of charitable activity in England and Wales between 2002 and 2007. 
In table 6 we report the results of the estimation of equation (1) for the whole sample. In columns (1) and (2) we report OLS and fixed effects estimators, while in columns (3) and (4) the random effects and GMM-SYS are reported. Our most reliable benchmark is the last column (4). Since we know that the biases of OLS and fixed effects in estimating the coefficient on the lagged term coefficient are in opposite directions (Bond, 2002, pp. 4-5), the fact that GMM-SYS estimation of this coefficient lies between the two can be considered as confirmation of the adequacy of the chosen estimation methodology (Roodman, 2006). In terms of the standard GMM-SYS diagnostic test, the $\mathrm{AR}(1)$ and $\mathrm{AR}(2)$ tests are both reassuring, while the null hypothesis of correct instrumentation (Hansen test) is rejected at the $1 \%$ level. However, we are not overly worried by the failure of the test. Neither the Sargan nor Hansen tests should be relied upon too faithfully, as they are prone to weakness (Roodman 2006, p. 12). In order to detect possible bias from multicollinearity we have calculated the variance inflation factor (VIF) which ranged from 1 to 2.27, averaged 1.25, and never exceeded the threshold value of 5 (see O'Brien 2007).

Table 6 shows that there is a lagged effect $\left(\alpha_{1}\right)$ on $\ln \left(i s_{i, t-1}\right)$ of 0.44 in our preferred model. Having controlled for the other variables in the model, this implies that $44 \%$ of commercial revenue is 'explained' by commercial revenue in the previous year, a strong but not overwhelming level of persistence of commercial revenue in the same organisations over time. This would suggest that previous assumptions in the literature that commercial revenue is stable over time, and thus marks a rational resource diversification for charities (Froelich, 1999) should be revisited using up to date models. The sign of the coefficient $\left(\alpha_{2}\right)$ demonstrates that other things remaining equal a $10 \%$ decline in voluntary income is associated with a $3.1 \%$ increase in commercial revenue. Thus we can say that, at least in a small way, commercial revenue is a substitute for grants and donations.

\section{Table 6 Here}

We repeated the estimation of equation (1) for each of ten broad groupings of ICNPO categories. This allowed us to estimate the persistence and substitution effects for the different nonprofit fields of activity. In table 7 we report the estimation of equation (1) for the five sub-groups, based on ICNPO, where the substitution effect varied significantly from general representative charities. We only report the GMM-SYS estimations, our preferred approach.

We found significant differences in the persistence of commercial revenue $\left(\boldsymbol{\alpha}_{1}\right)$ across all fields of activity. This could be explained by the rapid changes in the policy environment 
effecting charities in some fields more than others. Certainly there would appear to be some (negative) connections between persistence effects and the extent of any substitution effect.

Of particular interest the substitution effect between voluntary and commercial revenue $\left(\boldsymbol{\alpha}_{2}\right)$ varies significantly from general representative charities in four of the ten fields (see Table 7). The fields of social services (-0.70) and law, advocacy and politics (-0.56) showed a greater substitution effect than the average for all charities. It may be that these fields in particular saw an increase in government funding through contracts to deliver public services over the period. Of particular interest is that for charities in the international field, commercial revenue is complementary to voluntary income. That is, other things being equal, a $10 \%$ increase in grants and donations is associated with an $8.6 \%$ increase in commercial revenue.

\section{Table 7 Here}

\section{Concluding Remarks}

We set out to explore whether charities in England and Wales were succumbing to market forces. Drawing upon a longitudinal dataset constructed from charities' annual returns between 2002 and 2007 we have confirmed existing findings that charities' reliance on earned income has increased relative to other revenue sources in England and Wales. The increase in commercial revenue occurred across almost all fields of activity.

Proving the marketisation thesis requires demonstrating that at the level of the individual charity, commercial revenue is a substitute for grants and donations. Using the GMM model to control for time and field effects, we have shown that commercial revenue was a relatively inelastic substitute for grants and donations over the period. Hence we can say with some degree of certainty that charities in England and Wales are increasingly dependent on commercial revenue, and that this is an inelastic substitute for grants and donations. We believe our study is the first to demonstrate and estimate this substitution effect in England and Wales. Moreover our study is, to the best of our knowledge, the first to demonstrate a statistically significant substitution effect using logged variables (and this controlling for, to some extent, any bias towards larger organisations.

However the substitution effect was relatively small and varied considerably by field of activity. Indeed in the international field the relationship between grants and donations and commercial revenue was complementary. While more work is necessary to begin to unpick the relationship between field of activity and revenue mix, we would tentatively speculate that the substitution effect has been partly driven by a change in the way government funds third sector organisations - from grants to contracts. Future research would ideally compare 
substitution effects across different time periods. Unfortunately there is no English data collected before 2002 which would allow this, and Guidestar UK no longer collects the data necessary to repeat our analysis in the periods after 2008. Work being undertaken by NCVO and the Third Sector Research Centre on a sample of charities will permit more sophisticated analysis in the future. However at the time of writing only two years of data have been collected. An alternative approach would be to compare England and Wales with countries where the move toward contract funding has already occurred (such as the United States). Of course this raises concerns about the comparability of data collected for (slightly) different purposes.

Our research has implications beyond providing an underpinning to the theoretical literature on marketisation. One part of the existing literature posits that turning to commercial revenue is a rational diversification for nonprofits as this revenue source is more stable than, and complementary to, grants and donations (Froelich 1999). It would seem that this prevailing mode of thought has influenced policy makers in England, at least in terms of the coalition government's Big Society agenda, with a dual emphasis on encouraging the commercialisation of third sector organisations while also encouraging philanthropic giving.

However as this paper has demonstrated, for the "average" third sector organisation commercial revenue is a partial substitute for grants and donations and the stability of commercial revenue may also be lower than has previously been assumed. Thus while it may be possible for governments to both change the ways third sector organisations are funded AND to stimulate an increase in aggregate giving, at the organisational level it would appear that trade-offs are made between commercial revenue and grants and donations.It is plausible that rather than creating a Big Society, the policy mechanisms put in place could actually create a split in civil society between organisations funded by commercial revenue to deliver goods and services, and more traditional civil society organisations funded through philanthropy and voluntary effort. More careful consideration of potential revenue sources may therefore be required by charities in different fields. To better enable charities to make these choices, foundations, governments and academics across the world should once more turn their attention to the interaction between different revenue sources available to nonprofits, particularly now that the tools to permit more intricate analyses are available.

\section{References}


Adaman, F., \& Madra, Y. (2002). Theorising the 'third sphere': A critique of the persistence of the 'economistic fallacy.' Journal of Economic Issues, 36(4), 1045-78.

Arellano, M., \& Bond, S. (1991). Some tests of specification for panel data: Monte Carlo evidence and an application to employment equations. The Review of Economic Studies, 58, 277-97.

Blundell, R., \& Bond, S. (1998). Initial Conditions and Moment Restrictions in Dynamic Panel Data models. Journal of Econometrics, 87, 115-43.

Bond, S. (2002). Dynamic panel data models: a guide to microdata methods and practice. London: Cemmap Working Papers, CWP09/02.

Carmel, E., \& Harlock, J. (2008). Instituting the 'third sector' as a governable terrain: Partnership, Performance and Procurement in the UK. Policy and Politics, 36(2), 155 71.

Carroll, D., \& Stater, K. (2009). Revenue Diversification in Nonprofit Organizations: Does it Lead to Financial Stability? Journal of Public Administration Research and Theory, 19(4), 947-966.

Caulier-Grice, J., Davies, A., Patrick, R., \& Norman, W. (2013). Social innovation practices and trends part II. Brussels: European Commission, DG Research.

Charity Commission. (2005). The Charities SORP 2005. London: The Charity Commission002E

Clifford, D., Geyne Rajme., F. \& Mohan, J. (2010). How dependent is the third sector on public sector funding? Southampton: Third Sector Research Centre Working Paper 45.

Dart, R. (2004). The legitimacy of social enterprise. Nonprofit Management and Leadership, 14(4), 411-424.

Davies, A., \& Simon, J. (2013). The value and role of citizen engagement in social innovation. Brussels: European Commission, DG Research.

Dees, J. G. (1998). Enterprising Nonprofits. Harvard Business Review, Jan-Feb, 55-67.

Dees, J. G. (2007). Taking social entrepreneurship seriously. Society, 44(3), 24-31.

Dees, J. G., Emerson, J., \& Economy, P. (2001). Enterprising Nonprofits: A Toolkit for Social Entrepreneurs. Wiley.

Dey, P., \& Steyaert, C. (2010). 'The Politics of Narrating Social Entrepreneurship.' Journal of Enterprising Communities, 4(1), 85-10.

Eikenberry, A. (2009). Refusing the Market: A Democratic Discourse for Voluntary and Nonprofit Organisations. Nonprofit and Voluntary Sector Quarterly, 38(4), 582-96. 
Eikenberry, A., \& Kluvert, J. (2004). The Marketisation of the Nonprofit sector: Civil society at risk? Public Administration Review, 64(2), 132-40.

Fischer, R. L., Wilsjer, A. L., \& Young, D. R. (2007). Exploring the Revenue Mix of Nonprofit Organisations: Does it relate to Publicness? Atlanta: Andrew Young School of Policy Studies Working Paper 07-32.

Foster, W., \& Bradach, J. (2005). Should Nonprofits Seek Profits? Harvard Business Review, Feb. 2005, 92-100.

Froelich, K. (1999). Diversification of Revenue Strategies: Evolving Resource Dependence in Nonprofit Organisations. Nonprofit and Voluntary Sector Quarterly, 28(3), 246-68.

Guo, B. (2006). Charity for Profit? Exploring Factors Associated with the Commercialisation of Human Service Nonprofits. Nonprofit and Voluntary Sector Quarterly, 35(1), 123 38.

Halfpenny, P., \& Reid, M. (2002). Research on the voluntary sector: An overview. Policy and Politics, 30(4), 533-50.

Hansen, L. (1982). Large Sample Properties of Generalised Method of Moments Estimators. Econometrica, 50, 1029-54.

Hansmann, H. (1987). Economic theories of nonprofit organisation. In W. Powell. (ed.), The Nonprofit Sector: A Research Handbook. Yale: Yale University Press.

Haugh, H., \& Kitson, M. (2007). The Third Way and the third sector: New Labour's economic policy and the social economy. Cambridge Journal of Economics, 31(6), 973-94.

Kerlin, J., \& Pollak, T. (2011). Nonprofit Commercial Revenue: A Replacement for Declining Government Grants and Contributions? American Review of Public Administration, 41(6), 686-704.

Kingma, B. R. (1995). Do profits crowd out donations, or vice versa? Nonprofit Management and Leadership, 6(1), 21-38.

LeRoux, K. (2005). What Drives Nonprofit Entrepreneurship? A Look at Budget Trends of Metro Detroit Social Service Agencies. American Review of Public Administration, $35(4), 350-62$.

Morgan, G. (2010). The use of charitable status as a basis for regulation of nonprofit accounting. Voluntary Sector Review, 1(2), 209-32.

Newman, J. (2007). Re-thinking 'The Public' in Troubled Times: Unsettling State, Nation and the Liberal Public Sphere. Public Policy and Administration, 22(1), 27-47. 
National Council for Voluntary Organisations (NCVO). 2010. UK Civil Society Almanac. NCVO.

Nicholls, A. 2010. The Legitimacy of Social Entrepreneurship: Reflexive Isomorphism in a Pre-Paradigmatic Field. Entrepreneurship, Theory and Practice, 34(4), 611-33.

Nickell, S. (1981). Biases in dynamic models with fixed effects. Econometrica, 49, 1417-26.

O'Brien, R. M. (2007). A Caution Regarding Rules of Thumb for Variance Inflation Factors. Quality and Quantity, 41(5), 673-690.

Okten, C., \& Weisbrod, B. A. (2000). Determinants of donations in private nonprofit markets. Journal of Public Economics, 75(2), 255-72.

Roodman, D. (2006). How to do xtabond2: an introduction to "Difference" and "System" GMM in Stata. Centre for Global Development Working Paper Number 103.

Rose-Ackerman, S. (1996). Altruism, Nonprofits and Economic Theory. Journal of Economic Literature, vol. Xxxiv, 701-28.

Salamon, L. (1993). The marketisation of welfare: Changing nonprofit and for-profit roles in the American welfare state. Social Service Review, 67(1), 16-39.

Salamon, L. (1997). Holding the centre: America's nonprofit sector at a crossroads. New York, Nathan Cummings Foundation.

Salamon, L., \& Anheier, H. (1998). Social origins of civil society: Explaining the nonprofit sector cross-nationally. Voluntas, 9(3), 213-48.

Sargan, J. D. (1958) The estimation of economic relationships using instrumental variables. Econometrica, 26(3), 393-415.

Segal, L. M., \& Weisbrod, B. A. (1998). Interdependence of donative and commercial revenues. In A. B. Weisbrod (ed.), To Profit or Not to Profit? (pp. 105-27). Cambridge: Cambridge University Press.

Teasdale, S. (2010). Models of social enterprise in the homelessness field, Social Enterprise Journal, 6(1), 23-34.

Teasdale, S., Alcock, P., \& Smith, G. (2012). Legislating for the big society: the case of the Public Services (Social Value) Bill. Public Money and Management, 32(3), 201-208.

Teasdale, S., Kerlin, J., Young, D., and In-Soh, J. (2013). Oil and water rarely mix: exploring the relative stability of non-profit revenue mixes over time, Journal of Social Entrepreneurship, 4(1), 69-87.

Tinkelman, D., \& Neely, D. G. (2011). Research Note: Some Econometric Issues in Studying Nonprofit Revenue Interactions Using NCCS Data. Nonprofit and Voluntary Sector Quarterly, 40(4), 751-761. 
Tsakalotos, E. (2005). Homo economicus and the reconstruction of political economy: six theses on the role of values in economics. Cambridge Journal of Economics, 29, 893908.

Weisbrod, B. (1975). Toward a theory of the voluntary nonprofit sector in a three -sector economy. In E. Phelps (ed.), Altruism, Morality and Economic theory. Russell: Sage.

Windmeijer, F. (2005). A finite sample correction for the variance of linear efficient two-step GMM estimators. Journal of Econometrics, 126, pp. 25-51.

Yetman, M., \& Yetman, R. (2003). The effect of nonprofits' taxable activities on the supply of private donations. National Tax Journal, 56(1), 243-58.

Yetman, M., Yetman, R., \& Badertscher, B. (2009). Calibrating the reliability of publicly available nonprofit taxable activity disclosures: Comparing IRS 990 and IRS 990- T data. Nonprofit and Voluntary Sector Quarterly, 38(1), 95-116. 


\section{Figures}

Figure 1. All general charities, commercial and total income since 2000/01 ( $£$ billions) (derived from NCVO, 2010)

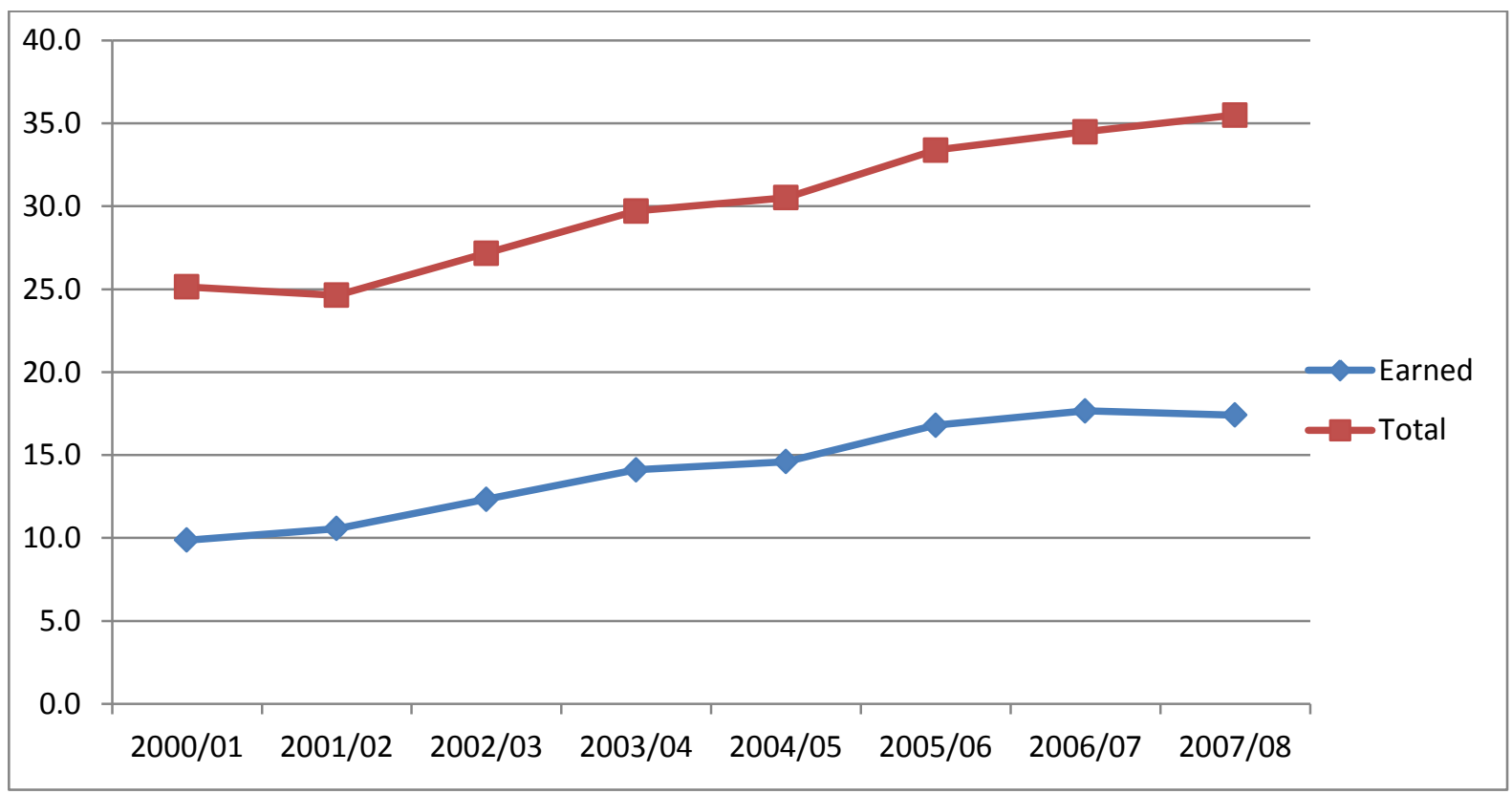


Figure 2. Commercial revenue as percentage of total, by field of activity, in 2003 and 2007

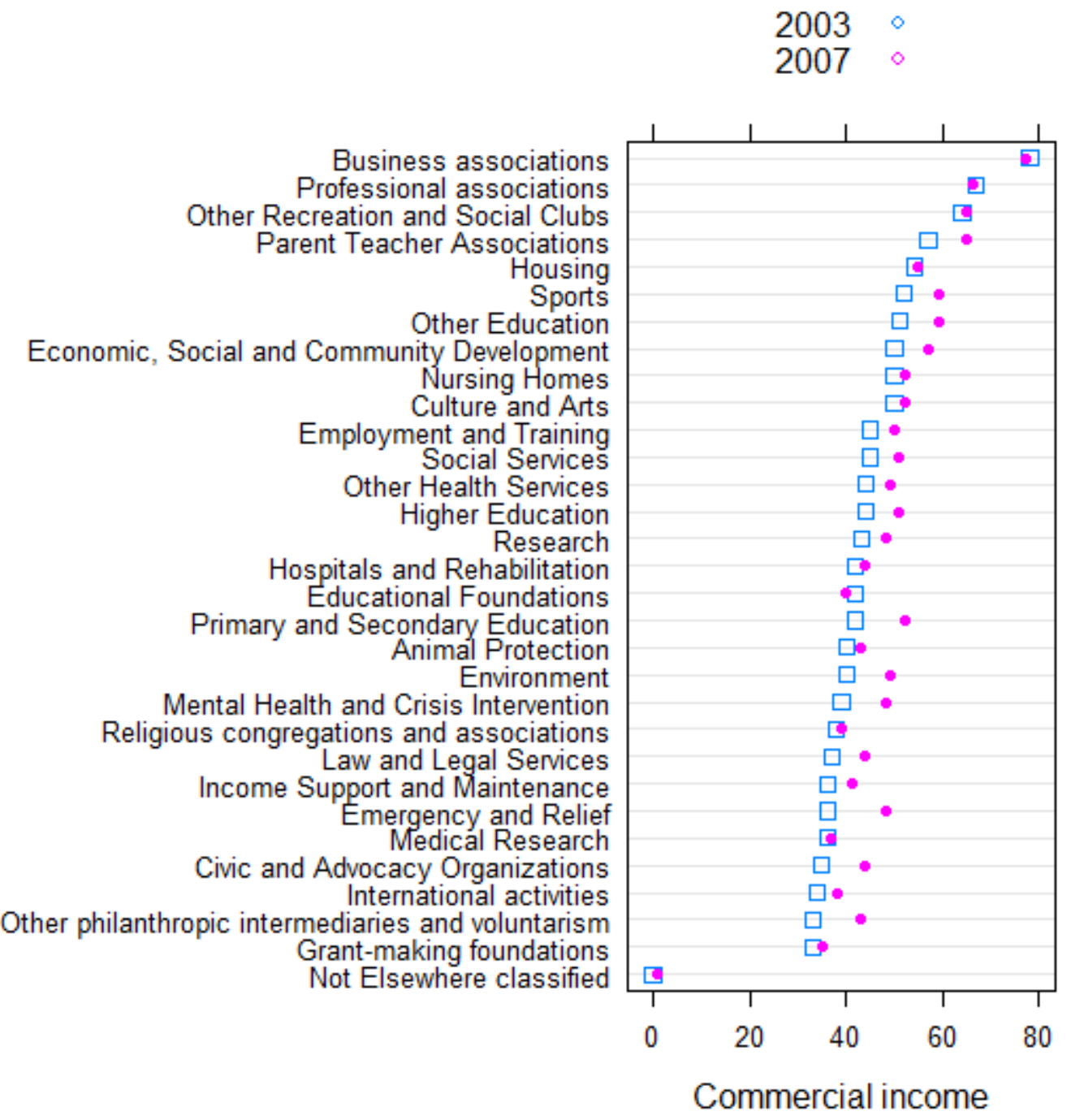




\section{Tables}

Table 1. Types of commercial revenue

Type of Commercial Revenue Description

Fees for service

Payments from recipients receiving goods and services directly from the organisations.

Contracts to supply services

Payments from government or other third parties for goods and services supplied.

Sales of products not directly

Payments for products which are additional to the associated with charitable activity charity's core mission. For example the sale of Christmas cards.

For-profit subsidiaries Profits derived from the activities of commercial organisations owned by the parent charity.

Fee for endorsing products This relates to a trend in the US for nonprofits to (advertising revenues) develop commercial relationships with for-profit companies and receive funds for endorsing products. 
Table 2. Changes in our variables of interest over time

\begin{tabular}{|c|c|c|c|c|c|c|}
\hline Year & $\begin{array}{l}\text { Mean } \\
\text { Income }\end{array}$ & $\begin{array}{c}\text { Mean } \\
\text { Commercial } \\
\text { revenue }\end{array}$ & $\begin{array}{c}\% \\
\text { Commercial } \\
\text { revenue }\end{array}$ & $\begin{array}{c}\text { Mean } \\
\text { Voluntary } \\
\text { income }\end{array}$ & $\begin{array}{c}\% \\
\text { Voluntary } \\
\text { income }\end{array}$ & N. obs \\
\hline 2003 & $£ 967,272$ & $£ 493,221$ & $51 \%$ & $£ 418,247$ & $43 \%$ & 15,412 \\
\hline 2004 & $£ 1,085,852$ & $£ 560,191$ & $52 \%$ & $£ 456,768$ & $42 \%$ & 14,317 \\
\hline 2005 & $£ 1,195,861$ & $£ 640,839$ & $54 \%$ & $£ 488,959$ & $41 \%$ & 14,042 \\
\hline 2006 & $£ 991,565$ & $£ 537,991$ & $54 \%$ & $£ 407,695$ & $41 \%$ & 18,385 \\
\hline 2007 & $£ 1,186,960$ & $£ 654,693$ & $55 \%$ & $£ 483,519$ & $41 \%$ & 15,468 \\
\hline
\end{tabular}


Table 3. Summary of proportion of total income that is commercial revenue in 2003-2007, derived using aggregate amounts for fields

$\%$ of overall income that is commercial revenue

\begin{tabular}{lccccc} 
Income Band (f) & 2003 & 2004 & 2005 & 2006 & 2007 \\
\hline $0-9,999$ & $44.9 \%$ & $54.6 \%$ & $54.6 \%$ & $39.0 \%$ & $44.7 \%$ \\
$10 \mathrm{k}-99,999$ & $46.9 \%$ & $46.8 \%$ & $47.0 \%$ & $45.8 \%$ & $49.0 \%$ \\
$100 \mathrm{k}-999,999$ & $49.8 \%$ & $46.2 \%$ & $47.6 \%$ & $48.9 \%$ & $50.8 \%$ \\
1, ML -10 ML & $57.4 \%$ & $53.5 \%$ & $55.5 \%$ & $58.1 \%$ & $58.2 \%$ \\
& & & & & \\
$10 \mathrm{ML}-100 \mathrm{ML}$ & $55.8 \%$ & $56.5 \%$ & $55.4 \%$ & $58.0 \%$ & $61.5 \%$ \\
100 ML- Plus & $35.2 \%$ & $44.4 \%$ & $52.1 \%$ & $48.0 \%$ & $44.0 \%$ \\
\hline Average & & & & & \\
\hline N. Charities & $51.0 \%$ & $51.6 \%$ & $53.6 \%$ & $54.3 \%$ & $55.2 \%$ \\
\hline
\end{tabular}

Table 4. Correlation matrix: income sources

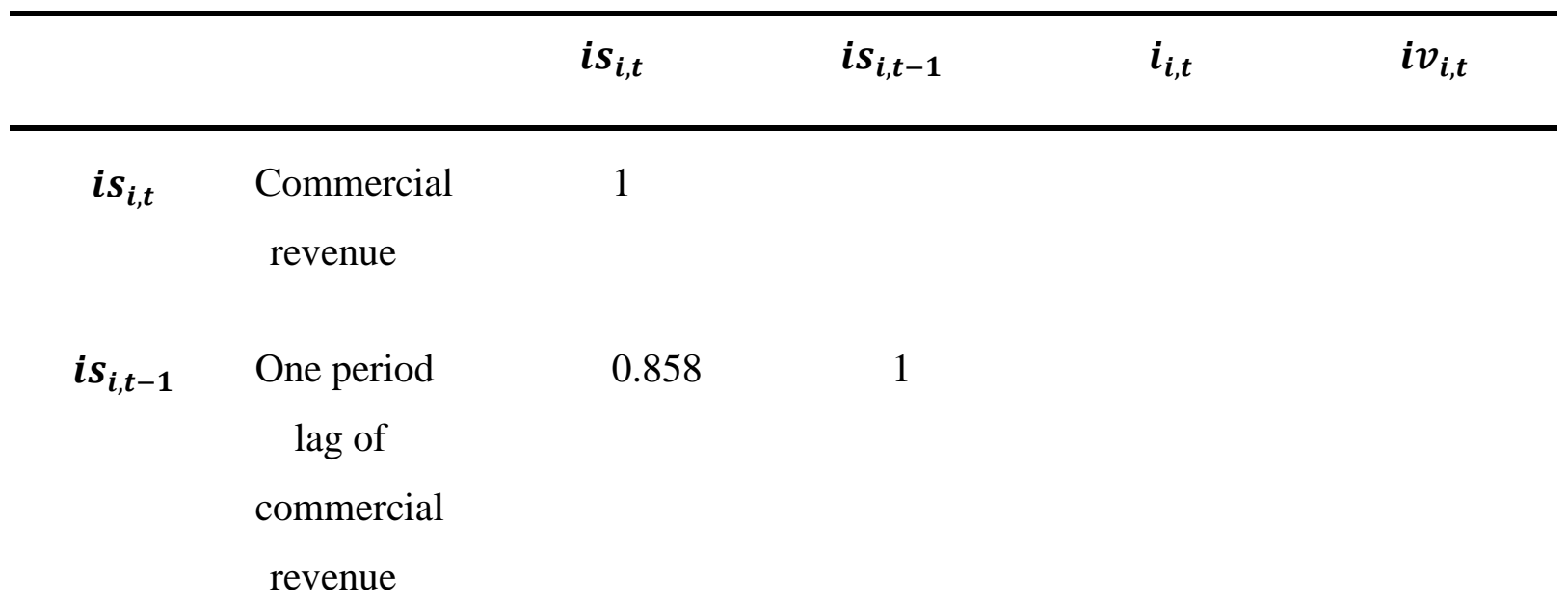




\begin{tabular}{|c|c|c|c|c|}
\hline $\boldsymbol{i}_{i, t}$ & $\begin{array}{r}\text { Total } \\
\text { revenue }\end{array}$ & 0.755 & 0.723 & 1 \\
\hline$i v_{i, t}$ & $\begin{array}{l}\text { Grants and } \\
\text { donations }\end{array}$ & 0.277 & 0.299 & 0.672 \\
\hline
\end{tabular}

Table 5. Total, between and within variation of incomes in the sample of charities analysed Standard Deviation

\begin{tabular}{ccccccc} 
& Mean & $\begin{array}{c}\text { Total } \\
\text { st. dev }\end{array}$ & Between & Within & $\begin{array}{c}\text { n. } \\
\text { charities }\end{array}$ & Observations \\
\hline $\mathrm{i}_{\mathrm{i}, \mathrm{t}}$ & $£ 1,080,025$ & $8,216,884$ & $6,364,110$ & $1,151,771$ & 33,581 & 77624 \\
$\mathrm{iv}_{\mathrm{i}, \mathrm{t}}$ & $£ 448,651$ & $4,414,996$ & $3,353,913$ & $1,244,772$ & 33,581 & 77624 \\
$\mathrm{is}_{\mathrm{i}, \mathrm{t}}$ & $£ 575,057$ & $4,679,832$ & $3,419,525$ & $1,384,740$ & 33,581 & 77624 \\
\hline
\end{tabular}


Table 6. Dynamic panel models of commercial revenue [ $\log (i s)]$

(3)

OLS Fixed effects Random effects GMM-SYS

\begin{tabular}{|c|c|c|c|c|}
\hline $\ln \left(i s_{i, t-1}\right)$ & 0.84 & 0.08 & 0.70 & 0.44 \\
\hline & {$[0.002]^{* *}$} & {$[0.043]^{* *}$} & {$[0.002]^{* *}$} & {$[0.021] * *$} \\
\hline \multirow[t]{2}{*}{$\ln \left(i v_{i, t}\right)$} & 0.0176 & -0.177 & -0.010 & -0.312 \\
\hline & {$[0.002]^{* *}$} & {$[0.036]^{* *}$} & [0.024] & {$[0.161]^{*}$} \\
\hline \multirow[t]{2}{*}{ Constant } & 1.75 & 11.62 & 3.30 & 9.34 \\
\hline & {$[0.285]^{* *}$} & {$[0.061]^{* *}$} & {$[0.03]^{* *}$} & {$[1.748]^{* *}$} \\
\hline$S$ & Yes & No & Yes & No \\
\hline$T$ & Yes & Yes & Yes & Yes \\
\hline N Obs & 77,624 & 77,624 & 77,624 & 77,624 \\
\hline R-sq & 0.73 & 0.01 & 0.737 & \\
\hline Within & & 0.02 & 0.013 & \\
\hline between & & 0.07 & 0.737 & \\
\hline Hansen & & & & 6.22 \\
\hline $\mathrm{p}$ value & & & & 0.044 \\
\hline $\operatorname{AR}(1)$ & & & & -19.76 \\
\hline $\mathrm{p}$ value & & & & 0.000 \\
\hline $\operatorname{AR}(2)$ & & & & 2.03 \\
\hline $\mathrm{p}$ value & & & & 0.042 \\
\hline
\end{tabular}

Notes. *significant at 5\%;**significant at $1 \%$ 
Table 7. Statistically significant variations in substitution effect by field of activity, Dependent Variable $\log ($ is $)$, different ICNPO classification

\begin{tabular}{lccc}
\hline ICNPO Field & $\begin{array}{c}\mathrm{n} \\
\text { charities }\end{array}$ & Persistence effect & Substitution effect \\
\hline Culture and arts & 3,482 & $0.43^{*}$ & -0.32 \\
Social services & 7,199 & $0.39 *$ & $-0.69^{*}$ \\
$\begin{array}{l}\text { Law and legal } \\
\text { services }\end{array}$ & 791 & $0.30^{*}$ & $-0.56^{*}$ \\
International & 941 & & $+0.86^{*}$ \\
\hline Overall model & 33,581 & $0.59 *$ & $-0.31^{*}$ \\
\hline
\end{tabular}

Notes. *significant at 5\%;**significant at $1 \%$ 


\footnotetext{
${ }^{\mathrm{i}}$ We dropped the year 2008 from the final model as there were changes in the way Guidestar UK classified commercial revenue leading to a discontinuity with previous data.

${ }^{\text {ii }}$ Investment income is not explored further in this paper, as it makes up a relatively small proportion of charities aggregate income.

iii Which is freely available at http://data.ncvo-vol.org.uk/?p=75 .

iv This has since changed to $£ 250,000$

${ }^{v}$ The decline in mean revenues (across all categories) in 2006 is a consequence of a larger number of organisations being included in our sample in this year. While this affects the mean values it has no noticeable effect on the trend showing a gradual increase in the proportion of commercial revenue.

${ }^{v i}$ Data processing was carried out using Stata 11, and GMM estimations were conducted using the routine xtabond2; see Roodman (2006) for details.
} 